\title{
STRATEGI KOPING PADA SISWA SMA DI KOTA MALANG
}

\author{
Eska Prawisudawati Ulpa \\ Magister Psikologi \\ Universitas Muhammadiyah Malang
}

\begin{abstract}
ABSTRAK : Rintisan sekolah bertaraf internasional (RSBI) adalah sekolah nasional yang menyiapkan peserta didiknya berdasarkan Standar Nasional Pendidikan (SNP) Indonesia dan tarafnya internasional sehingga lulusannya memiliki kemampuan daya saing internasional. Standar yang berbeda ini dapat menjadi stresor siswa di sekolah. Strategi koping memainkan peran sebagai salah satu kunci dalam membantu siswa untuk mengatasi stres nya dan juga hambatan yang ditemui dalam proses akademisnya. Penelitian ini bertujuan untuk mengetahui bagaimana strategi koping yang digunakan siswa SMA RSBI di kota Malang. Penelitian ini menggunakan pendekatan kuantitatif dengan jumlah subjek sebanyak 100 orang, yaitu siswa SMAN 1, SMAN 3 dan SMAN 4 Malang. Pengumpulan data dilakukan dengan menggunakan metode kuesioner atau angket dengan reliabilitas sebesar 0,927. Berdasarkan hasil penelitian dapat disimpulkan bahwa strategi koping yang paling banyak digunakan siswa adalah penyelesaian masalah, kemudian restrukturisasi kognitif dan dukungan sosial. Hasil ini menunjukkan bahwa sebagian besar siswa menggunakan strategi koping yang engagement, yaitu strategi koping yang menunjukkan usaha keterlibatan individu dalam usahanya untuk mengatasi situasi stres secara aktif aktif dan berkelanjutan untuk mengatasi situasi yang mereka hadapi.
\end{abstract}

Kata Kunci : strategi koping, siswa, RSBI

PSIKOISLAMIKA. Jurnal Psikologi Islam (JPI) copyright @ 2015 Pusat Penelitan dan Layanan Psikologi. Volume 12 Nomor 1 Tahun 2015

\section{PENDAHULUAN}

Tuntutan di bidang akademis merupakan salah satu sumber stres pada siswa di sekolah (Hashim, 2003: Olpin, 1997). Memahami apa yang diajarkan guru, bersaing dengan teman sekelas, dan memenuhi apa yang diharapkan oleh guru dan orang tua (Lal, 2014). Siswa di Sekolah Menengah Atas mengungkapkan bahwa stres yang mereka rasakan di sekolah (seperti ujian, rangking, pekerjaan rumah, harapan dan pencapaian prestasi nantinya) merupakan stres terbesar mereka. Hasil-hasil penelitian ini menguatkan bahwa sebagian besar remaja mengalami stres dalam kegiatan akademisnya (Topper, 2007; Agolla dan Ongori, 2009).

Penelitian ini dilakukan pada siswa di sekolah yang merupakan rintisan sekolah bertaraf internasional (RSBI). RSBI adalah sekolah nasional yang menyiapkan peserta didiknya berdasarkan Standar Nasional
Pendidikan (SNP) Indonesia dan tarafnya internasional sehingga lulusannya memiliki kemampuan daya saing internasional (Djauhari, 2007). Sekolah ini merupakan sekolah unggulan dimana siswa-siswanya juga merupakan siswa pilihan. Dengan standar yang berbeda ini dapat menjadi stresor siswa di sekolah baik dikarenakan tugas, tuntutan, persaingan ataupun juga sistem yang berbeda dengan sekolah pada umumnya.

Stres akademis yang dialami siswa sering berhubungan dengan kecemasan dan depresi (Pury, 2002). Ketika situasi stres berlangsung maka siswa akan menjadi tidak teratur, bingung, kurang mampu untuk mengatasi, sehingga mereka menghadapi stres yang berhubungan dengan masalah kesehatan seperti ketegangan, tekanan, kecemasan, depresi dan frustrasi. Hal ini menunjukkan bahwa lebih banyak hal dan emosi negatif yang dirasakan oleh 
siswa yang mengalami stres akademis. Padahal siswa dalam proses belajar diharapkan memiliki emosi yang positif sehingga siswa dapat berkembang dan mencapai kesuksesan dalam akademisnya. Penelitian menunjukkan hubungan antara stres dan penurunan nilai serta kinerja lainnya pada siswa. Oleh karena itu, stres harus dapat diatasi dengan koping yang engagement (Stevenson dan Harper, 2006).

Strategi koping merupakan strategi yang mengarah pada apa yang dilakukan individu untuk mengatasi situasi stres atau tuntutan yang membebani secara emosional (Folkman dan Lazarus, 1984). Strategi koping yang dilakukan tiap individu bervariasi dan tidak selalu dapat membawa pada solusi dari masalah yang menimbulkan situasi stres. Individu melakukan proses penanggulangan terhadap stres melalui proses transaksi dengan lingkungan, secara perilaku dan kognitif.

Strategi koping menurut Tobin (2001) dibedakan menjadi engagement dan disengagement. Strategi koping engagement (keterlibatan) terdiri strategi koping yang menunjukkan usaha keterlibatan individu dalam usahanya untuk mengatasi situasi stres secara aktif aktif dan berkelanjutan untuk mengatasi situasi tersebut, yang berfokus pada masalah ditujukan untuk pemecahan masalah atau melakukan sesuatu untuk mengubah situasi. Sedangkan strategi koping disengagement (pelepasan) merupakan strategi koping dimana individu tidak menunjukkan bentuk keterlibatan atau usaha perubahan untuk mengatasi situasi stres.

Kemampuan strategi koping yang engagement dapat membantu remaja mengatasi stres akademis yang dialami. Strategi koping yang engagement dapat meminimalkan dampak stres terhadap kesejahteraan psikologis siswa (Park dan Adler, 2003). Keterampilan ini juga membantu siswa menjadi mandiri dan mampu memecahkan masalah yang nantinya akan membuat remaja lebih berhasil dalam bidang akademis serta dalam kehidupan sosialnya (Kadhiravan dan Kumar, 2012).

Penelitian pada remaja di Spanyol menunjukkan hasil bahwa remaja yang mengatasi stres dengan respon positif dan merencanakan tindakan untuk mengatasinya dapat berdampak positif bagi siswa (Gloria et al, 2005). Hal ini berarti strategi koping yang engagement memainkan peran sebagai salah satu kunci dalam membantu siswa untuk mengatasi stres nya dan juga hambatan yang ditemui dalam proses akademisnya (Gustems dan Calderon, 2012).

Strategi koping merupakan perubahan kognitif dan perilaku yang berlangsung terus menerus untuk memenuhi tuntutan eksternal atau internal yang dinilai sebagai beban atau melampaui sumber daya individu dan membahayakan well-beingnya (Folkman dan Lazarus, 1984).

Delapan bentuk strategi yang diuraikan Tobin (2001) dalam alat ukur Coping Strategy Inventory (CSI) yang juga diadaptasi dari kuesioner Ways of Coping dari Lazarus dan Wherry terdiri dari: 1. Problem Solving, strategi perilaku dan kognitif yang dirancang untuk mengurangi stres dengan cara mengubah situasi stres; 2. Cognitive Restructuring, strategi kognitif yang mengubah makna stres dengan menilai sisi positif dan melihat dari perspektif yang baru; 3. Express Emotion, strategi yang mengacu pada pelepasan dan pengekspresian emosi; 4 . Social Support, strategi untuk mencari dukungan dari keluarga, teman atau orang lain; 5. Problem Avoidance, strategi yang mengacu pada penolakan masalah dan menghindari pikiran atau tindakan yang berhubungan dengan peristiwa stres; 6 . Wishful Thingking, strategi kognitif yang berupa harapan bahwa keadaan akan menjadi lebih baik; 7. Self Criticism, strategi yang mengunakan cara dengan mengkritisi diri sendiri namun terkadang juga menyalahkan diri sendiri atas situasi yang terjadi; 8. Social Withdrawal, strategi yang berupa menghindari orang lain dan lebih banyak menghabiskan waktu sendiri.

Greenberg dan Valletutti (1980) menyatakan bahwa keseimbangan psikologis yang baik pada individu adalah alat yang efektif untuk mengatasi stres. Strategi untuk mengatasi stres disebut sebagai strategi koping; yang meliputi, perilaku, fisik, faktor eksternal, emosional, spiritual dan strategi kognitif (Lazarus, 1999; Lazarus \& Folkman, 1984). Strategi koping yang engagement mengurangi stres dan bermanfaat dalam jangka panjang serta mempengaruhi kesehatan fisik dan mental (Everley et al. 2002).

Strategi koping yang engagement dapat membantu siswa untuk bisa mengatasi hambatan yang mereka temui dalam kegiatan akademisnya. Bila siswa mampu mengatasi maka siswa akan lebih optimis dan mampu mempersiapkan dirinya, sehingga siswa akan menanggapi segala stresor yang dirasakannya sebagai tantangan yang mampu mengoptimalkan semua potensi yang siswa miliki. Siswa yang mampu melakukan ini akan menjadi siswa yang positif dan mencapai kesuksesan dalam kegiatan akademisnya. Penelitian ini bertujuan untuk mengetahui bagaimana strategi koping yang digunakan siswa SMA RSBI di kota Malang. 


\section{METODE}

Jenis penelitian yang dilakukan dalam penelitian ini adalah pendekatan kuantitatif. Penelitian ini dilakukan pada 50 siswa laki-laki dan 50 siswa perempuan siswa 2014/2015 di SMAN 1, SMAN 3, dan SMAN 4 Malang. Prosedur penelitian diawali dengan tahap persiapan, yaitu mempersiapkan instrumen yang digunakan sebagai alat ukur, melakukan survey awal, observasi tempat penelitian, dan mengurus perizinan, kemudian melakukan uji coba instrument. Setelah didapatkan hasil uji coba maka kemudian disiapkan instrumen yang sudah sesuai dengan hasil uji coba. Selanjutnya tahap pelaksanaan diawali dengan menyebarkan instrumen, skoring, dan setelah data-data terpenuhi dilakukan pengolahan menggunakan SPSS.

Strategi Koping diukur dengan skala Coping Strategy Inventory (CSI) diadaptasi dari kuesioner "Ways of Coping" Lazarus (Tobin, 2001). Instrumen ini dibedakan menjadi engagement dan disengagement. Strategi koping engagement (keterlibatan) terdiri strategi koping yang menunjukkan usaha keterlibatan individu dalam usahanya untuk mengatasi situasi stres secara aktif aktif dan berkelanjutan untuk mengatasi situasi tersebut. yang berfokus pada masalah ditujukan untuk pemecahan masalah atau melakukan sesuatu untuk mengubah situasi. Engagement terdiri dari problem focused engagement (problem solving dan cognitive restructuring) dan emotion focused engagement (express emotion dan social support). Sedangkan strategi koping disengagement (pelepasan) merupakan strategi koping dimana individu tidak menunjukkan bentuk keterlibatan atau usaha perubahan untuk mengatasi situasi stres. Disengagement terdiri dari problem focused disengagement (problem avoidance dan wishful thingking) dan emotion focused disengagement (self criticism dan social withdrawal).

Jumlah item yang valid pada penelitian ini adalah 53 item. Instrumen ini berbentuk skala likert dengan lima pilihan jawaban dari 1 sampai 5. Contoh item soal: saya mencoba untuk melihat situasi dari sudut pandang baru. Hasil uji reliabilitas CSI adalah 0,83 dan hasil penelitian di Malang koefisiensi CSI sebesar 0,927.

\section{HASIL}

Berdasarkan perhitungan yang telah dilakukan didapatkan hasil bagaimana strategi koping yang digunakan siswa SMA di malang. Strategi koping dilihat dari delapan dimensi pada instrumen CSI, sebagai berikut: 1. Problem Solving atau penyelesaian masalah, didapat mean sebesar 3,78 dan standar deviasi sebesar 0,54; 2 . Cognitive Restructuring atau restrukturisasi kognitif, didapat mean sebesar 3,68 dan standar deviasi sebesar 0,49; 3. Express Emotion atau ekspresi emosi, didapat mean sebesar 3,19 dan standar deviasi sebesar 0,$77 ; 4$. Social Support atau dukungan sosial, didapat mean sebesar 3,51 dan standar deviasi sebesar 0,56; 5. Problem Avoidance atau penghindaran masalah didapat mean sebesar 3,16 dan standar deviasi sebesar 0,56; 6. Wishful Thingking atau harapan, didapat mean sebesar 3,46 dan standar deviasi sebesar 0,64; 7. Self Criticism atau kritik diri, didapat mean sebesar 3,42 dan standar deviasi sebesar 0,$58 ; 8$. Social Withdrawal atau penghindaran sosial, didapat mean sebesar 2,63 dan standar deviasi sebesar 0,86.

Hasil penelitian ini menunjukkan bahwa strategi koping yang paling banyak digunakan siswa adalah penyelesaian masalah, kemudian diikuti restrukturisasi kognitif dan dukungan sosial. Ketiga dimensi ini merupakan bagian dari strategi koping yang engagement, menunjukkan usaha keterlibatan individu dalam usahanya untuk mengatasi situasi stres secara aktif aktif dan berkelanjutan untuk mengatasi situasi tersebut.

Hasil ini sejalan dengan penelitian yang dilakukan di Thailand bahwa strategi koping yang paling sering digunakan adalah mencari dukungan sosial (social support) sebesar $62,25 \%$ dan pemecahan masalah secara terencana (problem solving) sebesar 23,73\% (Hsiao et al, 2010). Kumar dan Nancy (2011) juga meneliti tentang strategi koping dan hasilnya menunjukkan bahwa mencari pengalihan (problem avoidance) dan mencari dukungan dari ahli atau profesional (social support).

Strategi koping koping yang digunakan siswa dapat menumbuhkan sikap optimis pada siswa bahwa mereka mampu mengurangi stres yang terjadi (Blake \& Vandiver, 1988), serta dapat memotivasi dan meningkatkan kecakapan siswa (Ragheb \& McKinney, 1993). Hal ini sejalan dengan yang diungkapkan Donaldson \& Prinstein et al (2000) bahwa strategi koping dapat bermanfaat bagi siswa dan membantu mereka mengatasi stres yang dialami.

\section{KESIMPULAN}

Berdasarkan hasil penelitian dapat disimpulkan bahwa strategi koping yang paling banyak digunakan siswa adalah penyelesaian masalah, kemudian diikuti restrukturisasi kognitif dan dukungan sosial. Hasil ini menunjukkan bahwa sebagian besar siswa menggunakan strategi koping yang engagement, yaitu 
strategi koping yang menunjukkan usaha keterlibatan individu dalam usahanya untuk mengatasi situasi

\section{DAFTAR PUSTAKA}

Agolla, J.E. and Ongori, H. (2009). An assessment of academic stres among undergraduate students: The case of University of Botswana, Edu. Res and Rev, 4 (2), pp. 063-070.

Blake, R.L., \& Vandiver, T. A. (1988). The association of health with stresful life changes, social supports, and coping. Family Practice Research Journal, 7 (4), pp. 205-218

Djauhari. 2007. SMP Negeri 1 Purwodadi Bakal menjadi SBI. http//:www.smkn1-purwodadi. net/ - 24k -

Donaldson, D., Prinstein, M. J., Danovsky, M., \& Spirito, A. (2000). A pattern of children's coping with life stres: Implications for clinicians. American Journal of Orthopsychiatry, 70 (3), pp. 351-359

Everley, G, Jr., Lating, J. A. (2002). Clinical guide to the treatment of the human stres response, 2nd Ed. New York: Kluwer Academic/Plenum Publishers

Gloria, A. M., Castellanos, J., Lopez, A., \& Rosales, R. (2005). An examination of academic nonpersistence decisions of latino undergraduates. Hispanic Journal of Behavioral Sciences, 27,202-223.

Greenberg, S. F., \& Valletutti, P. J. (1980). Stres \& helping professions. Baltimore: Paul $\mathrm{H}$. Brookes

Gustem, J., Calderon, C. (2012). Coping strategies and psychological well being among teacher education students. Journal Psychol Educ. DOI 10.1007/s10212-012-0158-x

Hashim, I. H. (2003). Cultural and gender differences in perceptions of stresors and coping skills. A Higher Education, pp:254-268.

Hsiao, Y. C., Chier. Y., Wu L. T., Chiang, C. M., Huang, S, T. (2010). Spiritual health, clinical stres secara aktif aktif dan berkelanjutan untuk mengatasi situasi yang mereka hadapi.

practice stres, depressive tendency and healthpromoting behaviors among nursing students. Journal of Advanced Nursing, 66(7), 1612- 1622

Khadiravan, S., \& Kumar, K. (2012). Enhancing stres coping skills among college student. Journal of Arts, Science and Commerce. 4 (1).

Kumar, R., \& Nancy (2011). Stres dan coping strategies among nursing students. Nursing and Midwifery Research Journal, 7(4), 141-151.

Lal, K. (2014). Academic stres among adolescent in relation to intelligence and demographic factors. American International Journal of Research in Humanities, Arts and Social Sciences. 14, 123-129

Lazarus, R. (1999). Stres and emotions. . New York: Springer.

Lazarus, R., \& Folkman, S. (1984). Stres, appraisal, and coping. New York: Springer.

Park, C. L., Adler, N. E. (2003). Coping styles as a predictor of health and well-being across the first year of medical school, Health Psychology, 22 (6): 627-631

Pury, C. L. (2002). Information-processing predictors of emotional response to stres. Cognition and Emotion, 16, 667-683.

Ragheb, K.G., \& McKinney, J. (1993). Campus recreation and perceived academic stres. Journal of College Student Development, 34, pp. 5-10.

Stevenson A, Harper S (2006). Workplace stres and the student learning experience, Qual. Assur. Educ., 14(2): 167-178.

Tobin, D, L. (2001). User manual for the coping strategies inventory. Unpublished manuscript.

Topper, E. F. (2007). Stres in the library workplace. New Library World, (11 / 12): 561-564 


\section{MANUAL PENULISAN}

Psikoislamika, Jurnal Psikologi Islam (JPI) menerima tulisan berupa hasil penelitian, artikel, dan resensi buku, dalam bahasa Indonesia maupun Inggris, dengan ketentuan sebagai berikut:

1. Naskah bersifat orisinil dan belum pernah dipublikasikan dalam media lain.

2. Dapat dikirim melalui email dengan panjang tulisan antara 4500-5000 kata.

3. Naskah untuk resensi buku tidak lebih 1000 kata.

4. Sumber kutipan dan rujukan dicantumkan secara jelas dengan menggunakan in note, disertakan dengan tatacara penulisan APA (American Psychological Association) atau dapat menggunakan fasilitas penulisan rujukan di Microsoft Office.

5. Naskah yang akan dipublikasikan, terlebih dahulu diputuskan melalui dewan redaksi dan bagi naskah yang diterima akan dikomunikasikan lebih lanjut. Tulisan tidak memenuhi kualifikasi dewan redaksi, pengirim naskah akan diberitahu namun tanpa mengembalikan naskah aslinya.

6. Bagi naskah yang diterima, penulis diharapkan memenuhi beberapa kriteria yang telah ditentukan oleh redaksi. Oleh karena itu, penulis naskah diharapkan memenuhi standar aturan penulisan yang telah ditentukan atau melakukan revisi jika dewan redaksi memberikan umpan balik.

7. Menyertakan curiculum vitae singkat (maksimal 7. 50 kata), jabatan/pekerjaan sekarang, nama lembaga tempat bekerja, nomor telepon dan alamat email penulis.

Sistematika dan isi naskah untuk penelitian memuat sejumlah kriteria subjudul sebagai berikut:

1) Abstrak. Memuat setidaknya tujuan, teori, metode, analisis dan kesimpulan hasil penelitian. Ditulis dalam bahasa Inggris untuk tulisan yang berbahasa Indonesia dengan komposisi maksimal 150 kata dan disertai katakunci.

2) Muqadimah. Memuat latarbelakang masalah dan tujuan penelitian terkait dengan penelitian sebelumnya. Menghindari format penulisan model tesis atau disertasi agar tidak terkesan formal. Muqadimah maksimal ditulis tidak lebih dari 3 paragraf.

3) Kerangka kerja teoritik (conceptual framework). Mendeskripsikan kerangka kerja teori penelitian secara padat dan penurunan hipotesisnya (jika ada). Ditulis secara langsung menjadi satu kesatuan (tidak terpisah).

4) Metode. Mencakup; sampel, instrument (alat penelitian) dan langsung dijelaskan analisis validitas dan reliabilitas, prosedur penentuan responden atau tatacara pengambilan data dan informasi teknik analisis data.

5) Hasil. Mendeskripsikan cakupan hasil analisis statistik untuk menjawab pembuktian hipotesis mayor atau minor.

6) Diskusi. Memungkinkan verifikasi teori atau memperkuat dengan membandingkan teori, membahas dialektikan sub-sub variabel hasil analisis, membuat penegasan, menyarankan variabel tertentu karena alasan khusus dengan cara memperluas atau mempersempit kaidah atau sampai batas menyusun teori dari temuan penelitian.

7) Kesimpulan. Menegaskan pencapaian tujuan dan kesimpualn terhadap pembuktian hipotesis dan saran untuk pemanfaatan hasil penelitian dan bentuk tidak lanjut bagi penelitian selanjutnya.

Kategori penulisan opini ilmiah (theoritical overview), disarankan agar penulis menyajikan kerangka teori-teori yang lebih baru dan menyertakan pendapat pribadi dalam ulasan berbentuk diskusi. Bagi penulis yang berminat untuk meninjau buku (resensi) juga disertakan sejumlah kelebihan, manfaat dan timbangan kritis terhadap kekurangan dari pemikiran dalam buku yang sedang ditinjau.

\section{Submission}

Psikoislamika, Jurnal Psikologi Islam (JPI) untuk edisi mendatang. Redaksi mengundang kepada para pakar atau peneliti untuk ikut menjadi kontributor bagi pengembangan psikologi Islam dari berbagai perspektif kajian (interdisipliner), terutama pengembangan psikologi Islam yang berorientasi kepada pengembangan khazanah kesehatan mental melalui eksplisitasi nilai-nilai islam dan untuk tujuan kemaslahatan umat li kulli zaman wa makan. 